\title{
ENGLISH AS A COURT LANGUAGE IN CONTINENTAL COURTS
}

\author{
Christoph A. Kern ${ }^{*}$
}

\begin{abstract}
Most recently, several countries on the European continent have admitted, or are discussing to admit, English as an optional court language. This article provides some information about the background of these recent initiatives, projects and reforms, clarifies the idea on which they are based and explores the purposes they pursue. It then identifies in a theoretical way the various possible degrees of admitting English as a court language and the surrounding questions of practical implementation. These general issues are followed by a presentation of the initiatives, projects and reforms in France, Switzerland and Germany. Not surprisingly, the idea of admitting English as a court language has not only found support, but has also been criticized in legal academia and beyond. Therefore, the article then attempts to give a structured overview of the debate, followed by some own thoughts on the arguments which are being put forward. It concludes with an appeal not to restrict the arguments in favour of admitting English as a court language to merely economic aspects, but also to give due weight to the fact that admitting English may facilitate access to justice and may result in bringing back cases to the public justice system.
\end{abstract}

Keywords: Court language; Flight from the public justice system; Problems of translation; Development of the law; Language politics

\section{Introduction}

The mere notion of 'dispute resolution' implies the prior existence of a dispute. Whenever a third person is involved in the process of resolving a dispute, it is indispensable that the parties communicate the facts the dispute is about, their claims and their understanding of the applicable rules to this third person. The third person, on its turn, will then communicate with the parties to help them in resolving their dispute, will make a proposal or impose a binding decision. The means of communication is language, be it by written or oral words. With court proceedings being a formalised type of dispute resolution according to legal parameters, it comes as no surprise that the language to be used for communication within such proceedings is determined by law. ${ }^{1}$ Leaving aside for a moment the countries with more than one official language or with minorities using their own language, a necessity to determine which language the parties and the court must use could only come up in times when there was either a reason for serious doubt about the appropriate language or an external motivation for a rule on the language to be used in courts. Serious doubt arose at the end of the Middle Ages when Latin lost its position as lingua franca and, subsequently, as 'official' language in most European states, but also when newly conquered territories had to be integrated into a state with another linguistic culture ${ }^{2}$ an important, and sometimes coinciding, external

Dr. Christoph A. Kern, LL.M. (Harvard), professor, chair of Private Law, Private International Law, Comparative Law and Procedural Law at EBS Law School, Wiesbaden. The author wishes to express his gratitude to Maître Anne-Caroline Urbain, LL.M. (Harvard), admitted to the bars of Paris and New York, for her support in researching the current situation in France, as well as PD Dr. Alexander Brunner, Commercial Judge, Zurich, for his support in researching the situation in Switzerland. Remaining errors are the sole responsibility of the author.

$C f$. also G. Maier-Reimer, 'Vertragssprache und Sprache des anwendbaren Rechts', 63 Neue Juristische Wochenschrift (NJW) 2545, at 2545 (2010); and P. Kirchhof, 'Justitia spricht deutsch', Frankfurter Allgemeine Zeitung (FAZ) of 16 May 2008, at 37.

$C f$. for statutes allowing French in Courts of then-German Alsace-Lorraine after 1871 Royal Decree of 17 September 1874 and $\S 12$ EGBGB (Introductory Act to the Act on Court Organization) of 27 January 1877, RGBl. (Official Journal of the German Empire) 1877, at 77, 79. 
motivation was the emergence of a feeling of national identity. ${ }^{3}$ In France, for example, François $1^{\text {st }}$ ordered as early as 1539 in the Ordonnance de Villers-Cotterêts that French be the only language to be used in the courts of France. ${ }^{4}$ The German empire, to the contrary, adhered to a dualism of Latin and German as official languages until the end of the $18^{\text {th }}$ century, ${ }^{5}$ and only the codification movement made clear that German was to become the language of the law. ${ }^{6}$

Today, we are far away from times of such fundamental changes in European history. For decades, it has been clear that, as a matter of principle, the language to be used in courts is the official language or one of the official languages of the respective state. In the last few years, however, several initiatives, pilot projects and reforms on the European continent have started to challenge this parallelism. These initiatives, projects and reforms $\mathrm{s}^{7}$ have in common that they allow or seek to allow the use of other languages in court proceedings that are not the official language in the respective state. Their common idea is not that national courts should offer to proceed in each and any language the parties select. Their idea is rather to add one or more languages that are regarded as being especially 'important'. English figures most prominently among these languages.

It is the aim of this article to inform the reader about these recent projects and the debate they have spurred. Before doing so, it seems appropriate to say a few words about the background from which these projects have sprung (Section 2), to clarify the idea behind these projects (Section 3) and to ask which purposes its advocates pursue (Section 4). This discussion of the fundamentals shall be completed with a general overview on the measures that could be taken and their practical implementation (Section 5). The subsequent presentation of the projects (Section 6) will draw on the classification of measures and the considerations about their implementation. The article will then turn to the criticism these projects have received (Section 7) - criticism that is particularly intense in Germany. The conclusion (Section 8) shall contain some personal thoughts about the perspectives.

\section{The Background}

Without any doubt, English has become the dominant language in international business and international commercial law. ${ }^{8}$ Almost all cross-border transactions, from the sale of goods and the provision of services over the M\&A business to the creation and transfer of financial products, are governed by contracts written in English language. Even in important transactions within one and the same continental European country, the parties frequently resort to English, although English is neither the country's official language nor at least a habitual language in everyday life, and although none of the persons involved in the transaction is a native English speaker. Very often, the choice of the English language goes hand in hand with the choice of English or Anglo-American

\footnotetext{
For France, see, as an early example, J. du Bellay, La Deffence, et illustration de la Langue Francoyse (1549). See also F. Coulmas, Die Wirtschaft mit der Sprache (1992), at 146 (on the introduction of the Arab language as official language in Morocco after its independence in 1956).

4 Ordonnan[ce] du Roy sur le faict de justice, Art. 111. De prononcer et expedier tous actes en langaige françoys Et pour ce que telles choses sont souventesfoys advenues sur l'intelligence des motz latins contenuz es dictz arretz. Nous voulons que doresenavant tous arretz ensemble toutes aultres procedeures, soient de nous cours souveraines ou aultres subalternes et inferieures, soient de registres, enquestes, contractz, commisions, sentences, testamens et aultres quelzconques actes et exploictz de justice ou qui en dependent, soient prononcez, enregistrez et delivrez aux parties en langage maternel francoys et non aultrement.

5 See, e.g. Wahlcapitulation of the Holy Roman Emperor Francis II of 1792, Art. XXIII, § 3: ‘... keine andere Zunge noch Sprache ..., dann die teutsche und lateinische;' ('... no other tongue nor language ..., than the German and Latin [language];').

6 H. Hattenhauer, Zur Geschichte der deutschen Rechts- und Gesetzessprache (1987), at 34ff.; and P. von Polenz, Deutsche Sprachgeschichte vom Spätmittelalter bis zur Gegenwart, Vol. II (1994), at 51-54.

In the following, the word 'project' is used uniformly to cover mere initiatives, official projects and accomplished reforms.

${ }_{8}$ See generally, inter alia, Coulmas, above n. 3, at 357-364; D. Crystal, English as a Global Language, 2nd edn. (2003); and C. Mair (ed.), The Politics of English as a World Language (2003).
} 
(e.g. New York) law and the prorogation of a forum in England or the United States or an arbitration clause determining that the place of the arbitration be in an Englishspeaking country. ${ }^{9}$

These phenomena are nothing new, though. They alone do not suffice to explain why a number of continental European countries have, almost at the same moment, begun to think about admitting English as a court language, and started projects in that direction. Even if one assumes that in all continental European countries, court dockets of commercial cases have significantly decreased over the last few years, ${ }^{10}$ thereby making these phenomena particularly visible, the coincidence of discussions, initiatives, projects and reforms remains startling. Is there, one might ask, something beyond the phenomena described above that could explain this coincidence?

The answer should be: Yes, there is. The continental European countries, in which court proceedings were traditionally regarded as a necessary evil, have woken up and realized that there may be some value in having certain types of cases, namely big commercial cases, decided in the own national courts. The wake-up call ${ }^{11}$ was, it seems, the brochure England and Wales: The jurisdiction of choice, published by the Law Society of England and Wales and sponsored primarily by large English law firms. ${ }^{12}$ This brochure is a blunt advertisement for the lawyers, courts, and contract law of England and Wales, backed by the support of the then Secretary of State for Justice and Lord Chancellor, Jack Straw. Confronted with the brochure's various attacks on civil law systems ${ }^{13}$ and its presentation of legal rules that can be found in many modern legal systems as if they only existed in England, ${ }^{14}$ lawyers and politicians on the European continent felt a need to react. ${ }^{15}$ In Germany, the Federal Chamber of German civil law notaries (BNotK), the German Notaries' Association (DNotV), the German Federal Bar (BRAK), the German Bar Association (DAV) and the German Judges Association (DRB) published a brochure entitled 'Law - Made in Germany' nota bene: in German and English language. ${ }^{16}$ The same associations, together with the

See, e.g. C. Armbrüster, 'Englischsprachige Zivilprozesse vor deutschen Gerichten?', 44 Zeitschrift für Rechtspolitik (ZRP) 102, at 103 (2011); G.-P. Calliess and H. Hoffmann, 'Kammern für internationale Handelssachen - folgt die Justiz der Anwaltschaft auf dem Weg in die Globalisierung?', 41 BRAKMitteilungen (BRAK-Mitt) 247, at 249 (2010); H. Schwan, 'Bitte Eintreten, "English spoken", $F A Z$ of 24 February 2010, at 42; and for statistical data, see, e.g. the Oxford Civil Justice Survey 2008, available at http://denning.law.ox.ac.uk/iecl/pdfs/Oxford\%20Civil\%20Justice\%20Survey\%20-\%20Summary\%20 of\%20Results, \%20Final.pdf (last visited 28 July 2012).

${ }_{10}$ See for Germany G.-P. Calliess and H. Hoffmann, 'Effektive Justizdienstleistungen für den globalen Handel', 42 ZRP 1, at 4 (2009); Calliess and Hoffmann, above n. 9, at 247-248; H. Hoffmann, 'Englisch als Gerichtssprache? Pro', 43 ZRP 130, at 130 (2010); M. Illmer, 'Ziel verfehlt - Warum Englisch als Verfahrenssprache in $\S 1062$ ZPO zuzulassen ist', 44 ZRP 170, at $171 \mathrm{n} .14$ (2011); and O. Jauernig and B. Hess, Zivilprozessrecht, 30th edn (2011), at 21 n. 1.

$11 C f$. R. Müller-Piepenkötter, 'Englisch als Gerichtssprache', 88 Deutsche Richterzeitung (DRiZ) 2, at 2 (2010); A. Remmert, 'Englisch als Gerichtssprache: Nothing ventured, nothing gained', 30 Zeitschrift für Wirtschaftsrecht (ZIP) 1579, at 1579 (2011). On the traditional reticence and the difficulties of the German legal culture in marketing German law, see R. Stürner, Markt und Wettbewerb über alles? (2007), at 71f.; R. Stürner, 'Schlussbetrachtung und Ausblick', in 41 Jahrbuch Bitburger Gespräche (2003), at 143, 150.

12 Available at <www.lawsociety.org.uk/documents/downloads/jurisdiction_of_choice_brochure.pdf $>$ (published 2007, last visited 28 July 2012); for an early criticism, see C.A. Kern, 'Perception, Performance and Politics: Recent Approaches to the Qualitative Comparison of Civil Justice Systems', 14 Zeitschrift für Zivilprozess International (ZZPInt) 445, at 493-495 (2009).

13 Law Society of England and Wales (above n. 12), at 8 (claiming, inter alia, that English law gives guidance 'with greater certainty than in many civil law systems', that 'English law is based on the principle of freedom of contract which is more flexible than many civil law systems' - no freedom of contract in the civil law?).

14 Id., at 9 (noting, e.g. that ' $[a] n$ English judgment can be easily enforced within the European union by virtue of the Brussels 1 Regulation and the European Enforcement order' - which is, of course, the same for judgments from all courts of EU member states, even including Denmark).

15 Similarly S. Huber, 'Prozessführung auf Englisch vor Spezialkammern für internationale Handelssachen', in R. Geimer et al. (eds.), Europäische und internationale Dimension des Rechts. Festschrift für Daphne-Ariane Simotta (2012), at 245, 246 ('answer' on the brochure of the Law Society). ${ }_{16}$ Available at <www.lawmadeingermany.de/Law-Made_in_Germany.pdf>, now in third edition (1st edition 2008, 2nd edition 2010, 3rd edition 2012, last visited 28 July 2012); for an analysis, see H. Kötz, 'Deutsches Recht und Common Law im Wettbewerb' 60 Anwaltsblatt (AnwBl) 1, at 7 (2010). 
German Women Lawyers Association (djb) and the Federal Ministry of Justice (BMJ), established an 'Alliance for German Law' whose purpose it is to coordinate efforts to reinforce the position of German law in the global competition of legal systems. ${ }^{17}$ In France, the Foundation of French Notaries, the French National Bar Council and the Caisse des dépôts et consignations, together with a number of French corporations, created the 'Fondation pour le droit continental/Civil Law Initiative', a governmentally recognized public interest foundation with the mission 'to reinforce the dissemination of continental law at the global level and to ensure its position as a point of reference on an international scale' ${ }^{18}$ French and German associations, together with the Universite Panthéon-Assass and with the support of the two ministers of Justice, prepared another bilingual brochure on 'Continental Law', adding in a subtitle the characteristics 'global', 'predictable', 'flexible' and 'cost-effective' ${ }^{19}$ As strange as this may seem at first, the recent projects to admit English as a court language are part of this new policy to defend continental law and continental courts.

\section{The Idea}

The idea behind the initiatives and projects on English as a court language is simple: Foreign parties are often not familiar with the official language of continental European courts. However, virtually all players in international commerce are familiar with English. If continental European courts offered proceedings in English, the reasoning goes, linguistic difficulties would no longer be a motive to avoid continental European courts and resort to English or American courts or arbitration. ${ }^{20}$

With the obstacle of language overcome, the door seems to be open for true and fair competition based on the quality of civil justice systems and substantive law. According to the idea underlying the projects promoting English as a court language in continental courts, such competition could have two effects, both leading to the same desirable result. On the one hand, reportedly attractive features of continental courts, such as lean and cost-effective proceedings, would convince more parties to agree on a prorogation of a continental European forum instead of a forum in an English-speaking country or international arbitration in English. This, in turn, would also entail the choice of the law of the very forum, i.e. a law in the civil law tradition, as parties typically want the court to apply its own law. ${ }^{21}$ On the other hand, reportedly attractive features of continental substantive law, like predictability and consistency, should convince more parties to choose the law of a country of the continental legal tradition, were there no linguistic concerns about litigating in the language of the respective law. The choice of a law of the continental legal tradition, in turn, would also bring about the selection of a forum in the country of the applicable law or at least a place of arbitration in that country, again triggered by the consideration that courts should apply their own law. ${ }^{22}$

\footnotetext{
$17 C f$. BMJ/BNotK/BRAK/DAV/djb/DNotV/DRB, 'Ein Bündnis für das deutsche Recht', Positionspapier,

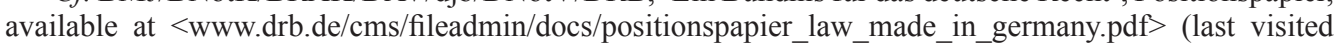
28 July 2012). For a general overview on the new commitment of German politics to the competition of legal systems, see I. v. Münch, Rechtspolitik und Rechtskultur (2011), at 134f.

18 Fondation pour le droit continental, <www.fondation-droitcontinental.org/jcms/c_5105/accueil $>$ (last visited 28 July 2012).

19 BNotK/BRAK/Conseil National des Barreaux/Conseil Supérieur du Notariat/DAV/DNotV/DRB/ Fondation pour le droit continental/Université Panthéon-Assass, Continental Law, available at $<$ www. kontinentalesrecht.de/tl_files/kontinental-base/Broschuere_DE.PDF> (last visited 28 July 2012).

20 See, e.g. Armbrüster, above n. 9, at 103; Remmert, above n. 11, at 1579.

21 See, e.g. Armbrüster, above n. 9, at 103; J. Dammann and H. Hansmann, 'Globalizing Commercial Litigation', 94 Cornell L. Rev. 1, at 18 (2008); T. Eisenberg and G. P. Miller, 'The Flight to New York: An Empirical Study of Choice of Law and Choice of Forum Clauses in Publicly-Held Companies' Contracts', 30 Cardozo L. Rev. 1475, at 1503ff. (2009); Müller-Piepenkötter, above n. 11, at 3; M. Spitz, 'Wird Englisch künftig Gerichtssprache?', 20 Melchers Law 5, at 6 (2010), available at <//www.melchers-law. com/fileadmin/user_upload/infobriefe/ML_20.pdf $>$ (last visited 28 July 2012).

${ }_{22}$ Cf. C. Braunbeck, 'May the Plaintiff Now File his Motion', 88 DRiZ, at 130 (2010).
} 


\section{The Purposes}

It needs no further explanation that an option to choose English as a court language in continental courts would at least contribute to the creation of a level playing field for the competition of civil justice systems and national laws. For anyone who believes in the oft-cited positive effects of competition among legal systems, the elimination of language as a distorting factor must be crucial to make sure that the competitive selection process works correctly. The projects promoting English in continental courts do indeed clearly aim at avoiding a distortion by language, which works to the detriment of continental courts and in favour of courts in English-speaking countries or in favour of international arbitration in English.

However, it would be naïve to assume that the advocates of the projects pursue nothing else than the idealistic purpose of ensuring undistorted competition for the sake of human progress, regardless of the outcome of the competition. What they also seek is the promotion of their own national courts and their own national law. In this respect, the projects are no better no worse than the marketing activities of the Law Society of England and Wales and other similar institutions in English-speaking countries like the American Bar Association or the American Law Institute, for which restoration of fair competition due to linguistic disadvantages obviously plays no role. Both the promotion of the own national courts and the promotion of the own national law are not so much driven by patriotism. First and foremost, they are driven by the aspiration to secure and expand profitable business for national courts and members of the national legal profession.

Regarding the courts, international commercial cases may be an important source of income for the national budget. ${ }^{23}$ This is particularly true in countries where the court fee depends on the value in dispute: ${ }^{24}$ As in international commercial cases the value in dispute typically is high, there is a good chance that the court fees cover or even exceed the costs the court incurs as a consequence of the litigation. ${ }^{25}$ Any surplus goes to the court's or state's budget and can help to subsidy small cases, thus improving access to justice in general.

Regarding the members of the legal profession, the starting point is that they normally only give legal advice as to the law of one single country, and that they only represent their clients in the courts of one single country - typically their home country. This is not merely a consequence of legal restrictions, but rather of the difficulty to have perfect knowledge of the law - procedural and substantive - and of the judicial habits of more than one country. Consequently, the members of the legal profession of a country benefit from any increase of litigation in the courts of their country as well as from any increase in the demand for legal advice on the law of their country. A prospering legal profession, in turn, develops a high level of legal expertise, which can be an important factor not only for the selection of the forum, but also for the decision where to incorporate or even run a business. According to this logic - which has some persuasive power, although there is no compelling empirical evidence for it -, attracting

${ }_{23} C f$. H. Prütting, 'In Englisch vor deutschen Gerichten verhandeln?', $60 \mathrm{AnwBl}$ 113, at 113 (2010); C.-P. Fink, 'Im Namen der Globalisierung', Die Zeit of 23 May 2010; J. Jahn, 'Deutsche Gerichte verhandeln nun auch auf Englisch' and 'Justitia International', FAZ of 9 January 2010, at 11.

${ }_{24}$ See, e.g. for the UK Civil Proceedings Fees (Amendment) Order 2011, Schedule 1; Germany $\S \S 3,34$ of the Act on Court Fees (Gerichtskostengesetz, GKG).

${ }_{25} C f$. Bundesrat, 'Entwurf eines Gesetzes zur Einführung von Kammern für internationale Handelssachen (KfiHG)', BR-Drucks. 42/10 of 27 January 2010, available at <http://dipbt.bundestag.de/dip21/ brd/2010/0042-10.pdf $>$ (last visited 28 July 2012), Explanatory Statement, at 14; $c f$. also Ministry of Justice, 'Fees in the High Court and Court of Appeal Civil Division', Consultation Paper CP15/2011 of 15 November 2011, available at <www.justice.gov.uk/downloads/consultations/appeal-high-court-feesconsultation.pdf/> (last visited 28 July 2012), at 20f. (para. 38), noting that it was the aim of the proposed reform 'that those whose cases consume more resource should be charged in a way that is proportionate to the cost incurred to the courts service'. See also Dammann and Hansmann, above n. 21, at 59-71 (proposing differentiated court fees in the sense of higher court fees for foreign litigants to motivate reforms) and Huber, above n. 15, at 255 (also suggesting higher fees). 
business for the legal profession in a country stimulates the creation of new jobs inside and outside the legal profession and implicates higher tax income. ${ }^{26}$

Finally, somewhat less in the foreground, but equally important is the wish to offer domestic companies the advantages of a proximate venue and an applicable law they are familiar with. For local companies it is normally convenient and less expensive if they can litigate in the courts and under the law of their home country. ${ }^{27}$ As compared with arbitration, proceedings in continental European courts are often less expensive, particularly if the value in dispute is rather modest. ${ }^{28}$ The advantage of litigating in a court in the home country applying that country's law is supposed to make domestic companies more competitive and thereby help to generate jobs and tax income. At the same time, this can attract foreign companies to re-incorporate in that very country, thereby again creating new jobs, tax income and, last but not least, business for the legal profession.

All this reminds us very much the case of Delaware. ${ }^{29}$ Delaware's courts and legislature also want to attract companies to incorporate there for fiscal reasons and with the intention to promote business for the members of the legal profession in its own state. Of course, the primary focus and the measures are somewhat different: The Delaware legislature is focussed on the incorporation of companies; it has no special interest in attracting legal disputes other than corporate law litigation. The measures taken by the Delaware legislature are, first and foremost, directed at constantly offering the most attractive - which frequently means: most permissive - substantive corporate law; questions of procedural law rank second and, obviously, enhancing the accessibility of domestic courts by permitting the use of a foreign language plays no role. Despite these differences, the purposes are the same, and the fact that other states in the U.S. have long been trying to imitate the example of Delaware is the best proof for the success of such policy.

\section{The Measures}

Getting back to continental Europe, which, then, are the measures that could be adopted to overcome the obstacle of a court language uncommon to most foreign parties and different from the language of the transaction documents? To answer this question, we should distinguish between the possible contents of such measures and their implementation.

\subsection{Their Possible Contents}

A first and relatively modest measure consists in accepting documents in a foreign language, in particular, English, without official translation. Traditionally, courts did not accept documents in a foreign language as documentary evidence unless the documents were accompanied by an official translation. However, such translations are costly and

\footnotetext{
26 Calliess and Hoffmann, above n. 9, at 248; Dammann and Hansmann, above n. 21, at 57; Hoffmann, above n. 10; Fink, above n. 23; Jahn, above n. 23, at 11; and Prütting, above n. 23, at 113.

27 BR-Drucks. 42/10, above n. 25, Explanatory Statement, at 7f.; and W. Ewer, 'Das Öffentlichkeitsprinzip - ein Hindernis für die Zulassung von Englisch als konsensualoptionaler Gerichtssprache?', 63 NJW 1323, at $1323(2010)$.

28 J. Gruber, 'Die bundesdeutschen Gerichte und der internationale Wirtschaftsverkehr', 23 ZRP 172, at 172 (1990); and Calliess and Hoffmann, above n. 9, at 248; and Huber, above n. 15, at 249f.

29 See, e.g. W.L. Cary, 'Federalism and Corporate Law: Reflections Upon Delaware', 83 Yale L.J. 663 (1974); A.F. Conard, 'An Overview on the Laws of Corporations', 71 Mich. L. Rev. 621, at 631ff. (1973); R. Romano, 'The State Competition Debate in Corporate Law', 8 Cardozo L. Rev. 709, at 740 ff. (1987); R. Romano, 'The States as a Laboratory: Legal Innovation and State Competition for Corporate Charters', 23 Yale J. on Reg. 209 (2006); H. Wells, 'The Modernization of Corporation Law, 1920-1940', 11 U. Pa. J. Bus. L. 573, at 576-580 (2009); R.K. Winter, 'State Law, Shareholder Protection, and the Theory of the Corporation', 6 J. Legal Stud. 251, at 254-262 (1977); for an early account in German language, see J. Flechtheim, 'Vom Aktienwesen in den Vereinigten Staaten. Reiseeindrücke', 3 RabelsZ 101, at 102f. (1929).
} 
time consuming, ${ }^{30}$ even more so as international commercial or financial transactions often comprise hundreds or thousands of pages of documents. In addition, there is a considerable risk of errors in the translation, as official translators are not always familiar with the terminology and technicalities of the facts and the legal theories at issue. Therefore, the necessity of an official translation may have a deterrent effect on potential litigants. Admitting documents in English as documentary evidence without restrictions would overcome this obstacle.

A second measure is the admission of written communication of the parties with the court and among each other in English. At first sight, this measure appears to be relatively insignificant. The costs and duration of translations regarding written communication within the proceedings will mostly be less important than the costs and duration of translations of documentary evidence, as the number and length of briefs is normally limited. Besides, the parties would normally engage a local counsel anyway. Nevertheless, it would be inaccurate to ignore the psychological effects of admitting written communication in English. If the parties can use English for any written communication within the proceedings, the directors and officers of the parties can read the original briefs of their own counsel as well as of the counsel of the other party. This gives them a feeling of direct control that the best translation and explanation by a local counsel cannot transmit.

From this second measure, one should distinguish, and therefore classify as a separate, third measure, the admission of oral communication with the court, the other party and the witnesses and experts in English. In commercial cases, oral communication seems to be of minor importance. However, at least as a matter of theory, most procedural laws assume, prefer or even require that applications, motions and petitions as well as pleadings and witness and expert interrogations be made orally. Court hearings with interpreters are very burdensome and costly, and the immediacy of the takings of evidence and the discussions suffer a lot. This is particularly true with regard to the deposition of witnesses and experts. Finally, in the rare case that a foreign director, officer or other representative of one of the parties who is proficient in English, but not in the language of the forum, takes part in a court hearing held in English, he or she is perfectly able to follow what is going on in the court.

From the admission of written communication in English, which was presented here as second measure, one should also distinguish the 'complete English file' as a fourth measure. The 'complete English file' goes further than the mere admission of written communication in that not only briefs and court letters can be composed in English, but the file in all its parts has to be in English. This encompasses any official forms, any summonses, any written communication to agree on dates for court hearings or deadlines, any internal writings of the court, i.e. writings only concerning the internal organisation of the proceedings, like orders to the clerks that something be sent by simple letter or by official service, and, most important, records of hearings and depositions in English. Obviously, a 'complete English file' eliminates linguistic difficulties with regard to all the written parts of the proceedings. This makes it easier for a foreign party or counsel to evaluate the prospects of an appeal and, as the case may be, prepare the appellate brief, for the question of what has been discussed and claimed in the first instance court as well as questions of procedural error are normally pleaded on the basis of the court file.

Finally, a fifth and very significant measure consists in using English not only during the proceedings, but also for the decisions of the court. When the proceedings or parts of them took place in English, a judge writing the decision in English can directly draw on the results of the proceedings, use the same English expressions and legal terminology that were used during the proceedings and quote from briefs or transcripts of depositions that are in the court file. The parties can understand the decision immediately and need not wait and pay for a translation. Although, as a matter of principle, all measures could be applied independently from each other, the fifth measure makes only sense if combined with some or all of the other measures.

30 See only X.E. Kramer, 'Over taalkwesties in de Europese Unie en de kunst van het juridisch vertalen', 24 Nederlands Internationaal Privaatrecht (NIPR) 254, at 254 (2006); and Huber, above n. 15, at 249. 


\subsection{Their Implementation}

The implementation of these measures is not as simple as it seems. Putting all other practical and legal problems aside, three issues are most fundamental.

First of all, in a country in which English is not an official language, it is not possible to expect that all parties have a sufficient knowledge of English. Therefore, any of these measures can only be applied when both parties agree. It follows that the court must, at a certain point in time, make findings on whether there is a valid agreement of the parties. For the parties, it is important to know beforehand whether they could have resort to proceedings in which one of these measures is available. This means that a clause providing for litigation before a continental European court in English must be binding not only with regard to the forum selection clause, but also with regard to the agreement on litigating in English language. Moreover, the purpose of attracting litigation to continental European courts can only be reached if the parties can be sure that their agreement will be honoured, i.e. that in case of an agreement to litigate in English, the court has no discretion to refuse this wish and can order to proceed in another language only under very limited circumstances.

Second, not all judges and court clerks can be expected to be fluent in English, either. Consequently, there must be a mechanism that a case in which English is to be used only comes to a judge and court staff with a sufficient knowledge of English. This can best be achieved by channelling such cases to certain designated judges or chambers or senates of judges with the respective staff regarding whom a sufficient knowledge of English is guaranteed. As long as the court has not yet found that there is a valid agreement of the parties on using English in court, the case must be dealt with by the judge, chamber or senate, which has jurisdiction according to the general rules. In case of an agreement, there must be a mechanism to transfer the case to the designated judge, chamber or senate.

Third, but related, it follows from the purpose of reducing obstacles for commercial disputes that these measures or some of them need not be available for all parties, for all disputes and in all types of proceedings. The legislature may therefore wish to add objective requirements and restrictions to the subjective requirement of party agreement. Possible objective requirements are that one of the parties be a foreign party or that the dispute be based on documents in English language, that the dispute have arisen from a contract or other pre-existing relationship and not from a tort, that the type of proceedings be documentary proceedings or the ordinary proceedings and not special proceedings like provisional measures, and so on. If - as is to be expected the legislature decides to make such restrictions, these restrictions should be clearly defined. ${ }^{31}$

\section{The Projects}

After this theoretical exposition, it is time to have a closer look at some of the current projects to introduce the use of English in continental European court proceedings. It goes without saying that the following presentation makes no claim to comprehensiveness. However, the presentation should suffice to exemplify what has been presented in more general terms above and to explain the reactions in the different countries, and may therefore serve as a basis for further research.

31 For a thorough discussion of the requirement of 'internationality', see Huber, above n. 15, at 256-258. 


\subsection{France}

\subsubsection{The Basic Rules}

As mentioned above, ${ }^{32}$ French has for centuries been the only admissible language in the courts of France. In 1992, article 2 of the constitution of 1958 was amended by an explicit rule according to which the language of the French Republic is French. ${ }^{33}$ Although the new civil procedure code of 1973-1975 provided in its article 23 that the judge is not obliged to have recourse to an interpreter if he or she knows the language in which the parties articulate themselves, ${ }^{34}$ the courts have until today been very reluctant to admit foreign languages, particularly regarding documentary evidence. ${ }^{35}$ Thus, over the first three decades of its existence, article 23 of the civil procedure code had not attracted much attention.

\subsubsection{Foreign Languages in the Tribunal de Commerce de Paris}

This was to change in November 2010, when the Tribunal de commerce de Paris announced that in its reading, the article permitted the creation of specialised chambers in whose proceedings documents in a foreign language could be accepted without translation and hearings could be held in a foreign language. ${ }^{36}$ It announced that the competent chamber was to be the third chamber, the 'chambre internationale', a chamber that traditionally had dealt primarily with cases of maritime transportation and insurance of non-French and non-European parties. ${ }^{37}$ The languages accepted by the court are English, German and Spanish, depending on the judges sitting in the case. ${ }^{38}$ A precondition for the admission of documents in a foreign language without translation and hearings without an interpreter is the consent of the parties. With the use of foreign languages being limited to hearings and documents, the language of the rest of the proceedings, especially the decisions, is to remain French. It should be noted that the judges in the commercial courts in France are not professional judges, but laymen elected from the commercial community ${ }^{39}$ - mostly directors and senior officers of important firms. Normally, these persons are perfectly familiar with business English and, in certain cases, also with German, Spanish and other languages due to

32 Above n. 4

33 Art. 2 as amended by Art. 1er of the Loi constitutionnelle n 92-554 du 25 juin 1992 ajoutant à la Constitution un titre: 'Des Communautés européennes et de l'Union Européenne', Official Journal (Journal Officiel) of 26 June 1992 at 8406.

${ }_{34}$ 'Le juge n'est pas tenu de recourir à un interprète lorsqu'il connaît la langue dans laquelle s'expriment les parties.'

${ }_{35}$ Cf., e.g. Cour d'appel de Paris, Pôle 5, chambre 4, judgment of 21 September 2011, N 09/10187, JurisData n 2011-024775: 'Considérant que les pièces [...], dès lors qu'elles n'ont pas fait l'objet d'une traduction en langue française en leur intégralité, ne peuvent qu'être écartées des débats'; chambre 1, judgment of 8 December 2010, N 08/19604, JurisData n 2010-027831: 'Mais considérant [...] que les indications [...] sur la liquidation de la société tim résultent de ses pièces 8 et 9 en langue allemande versées au débat sans traduction en français et ne peuvent être retenues comme moyens de preuves'.

36 Tribunal de Commerce de Paris, Press Release of 29 October 2010, 91 Les Annonces de la Seine N 57 (2011) of 18 November 2011, at 12, available at <http://issuu.com/adls/docs/les_annonces_de_la seine_57-2010_1290420880/> (last visited 28 July 2012).

$37 \quad \overline{C f}$. B. Auberger, 'La chambre internationale du Tribunal de Commerce de Paris', Juriste d'Entreprise Magazine N 10, Juillet 2010, at 61; C. de Baeque, 'Création d'une chambre internationale au Tribunal de commerce de Paris', interview available at <www.fondation-droitcontinental.org/jcms/c 9634/lettred-information-decembre-2010> (last visited 28 July 2012); C. Hausmann, 'Création d'une chambre internationale au Tribunal de commerce de Paris', Squire Sanders, La Revue, available at $<\mathrm{http}: / /$ larevue. ssd.com/MISCELLANEES_a1572.html> (last visited 28 July 2012).

38 Cf. C. de Baecque, 'Quel sera le droit applicable demain', 313 Gazette du Palais N 138/139 (2011) of 18/19 May 2011, at 5 (although not relevant here, it should be noted that the example on when a sale is perfect under German law [id., at 6] is not correct, but that, to the contrary, there is insofar no significant difference between French and German law), available at <www.nxtbook.fr/lextenso-editions/Gazette/ GazetteduPalais_DroitetCommerce_2011/index.php?startid=3\#/4> (last visited 28 July 2012).

${ }_{39}$ Art. L 721-1(1) Code de commerce. 
their professional functions. At least with regard to English, the court had good reasons to expect that, in its Paris circuit, no linguistic problems should occur. ${ }^{40}$ One may doubt whether any other language than English has been used so far. The official website of the Tribunal de commerce unfortunately provides no information.

In the classification of possible measures presented above, the 'chambre internationale' applies the first and third measures, i.e. documents and hearings in a foreign language. Whether in practice the use of foreign languages extends to some of the other measures as well is hard to determine. However, all available information clearly states that decisions must be rendered in French. Therefore, we can say for sure that the fifth possible measure is not being used.

In their implementation, the measures in the Tribunal de commerce premise, first, that both parties agree. Second, the scope of application is limited to cases within the jurisdiction of the commercial court. ${ }^{41}$ It seems that there is no special requirement of 'internationality'; however, one can assume that cases in which the parties wish to litigate before a French court in a foreign language regularly present 'international' aspects.

\subsection{Switzerland}

\subsubsection{The Basic Rules}

In Switzerland, the court language is the official language or one of the official languages of the canton of the forum. The official languages of the cantons are - solely or in combination - German, French, Italian and, as concerns inhabitants speaking this language, Rhaeto-Romanic, ${ }^{42}$ a proposal to make English the fourth official language ${ }^{43}$ was rejected by the Federal Council in $2007 .{ }^{44}$ In cantons with more than one official language, it is up to the cantons to enact rules determining which language is to be used in the proceedings ${ }^{45}$. It has traditionally been possible to present documents in a foreign language without translation if the court and the parties agree. ${ }^{46}$ An explicit rule to that effect was proposed for the new Federal Civil Procedure Code, ${ }^{47}$ but was not enacted law. Nevertheless, according to the law of the cantons, it is still possible to use a foreign language with consent of the parties and the court. ${ }^{48}$ Thus, as an example, the commercial court of Zurich accepts documentary evidence in English without translation, and some judges conduct hearings and the so-called 'conciliation at court' in English. However, the written communication within the proceedings, in particular, the complaint and other briefs, as well as the judgments, cannot be composed in English.

\footnotetext{
$40 \quad C f$. Auberger, above n. 37, at 61; and I. Smith Monnerville, 'Suing in English in a French Court', Sans Frontières N 12, September 2011, at 7, available at <www.sjberwin.com/Contents/Publications/pdf/65/ a6b8feab_1a52_4e6c_8f1b_c7a004f2d45a.pdf $>$ (last visited 28 July 2012).

41 On this jurisdiction, see Art. L 721-3ff. Code de commerce.

42 Art. 70(1) of the Federal Constitution of the Swiss Confederation (Bundesverfassung der Schweizerischen Eidgenossenschaft, BV).

${ }_{43}$ F. Gutzwiller, 'Prüfung der Einführung einer vierten Amtsprache', Anfrage of 5 October 2007, available at <www.parlament.ch/d/suche/seiten/geschaefte.aspx?gesch_id=20071108\#> (last visited 28 July 2012).

44 Bundesrat, Antwort of 28 November 2007, also available at <www.parlament.ch/d/suche/seiten/ geschaefte.aspx?gesch_id=20071108\#> (last visited 28 July 2012).

45 Art. 129 of the new Swiss Civil Procedure Code of 2008; the same was true before when each canton had its own procedural code, $c f$. M. Guldener, Schweizerisches Zivilprozessrecht (1979), at 261.

46 Guldener, above n. 45, at 261.

47 Bundesrat, Botschaft zur Schweizerischen Zivilprozessordnung of 28 June 2006, BB1. 2006, at 7221, 7306, available at <www.admin.ch/ch/d/ff/2006/7221.pdf > (last visited 28 July 2012).

${ }_{48}$ See, e.g. for Grisons Art. 7f. of the Law on languages (Sprachengesetz, SpG) of 19 October 2006.
} 


\subsubsection{The Proceedings in the New Patent Court}

By the Patent Court Act of 20 March 2009, Switzerland created a Federal Patent Court. ${ }^{49}$ The Court started its operation in January 2012. In this court, it is possible to litigate not only in one of the official languages German, French and Italian, ${ }^{50}$ but also in English if the parties and the court so agree. ${ }^{51}$ However, the decision and any orders concerning the proceedings must be composed in one of the official languages. ${ }^{52}$ Documents in a foreign language need not be translated if the court, with consent of the opposing party, dispenses from the requirement of a translation. ${ }^{53}$

These provisions realise the first and third and - probably - also the second measure in our classification: Documents, hearings and - possibly - also the communication with the court and the opposing party during the proceedings may be in English. However, there is no 'complete English file' and the decisions cannot be rendered in English. Thus, the fourth and fifth measures are not available.

As for the implementation of the measures, we find again the requirement of mutual consent. The scope of application is limited to patent cases as determined by the new act. ${ }^{54}$ There is no requirement of 'internationality', though.

\subsection{Germany}

\subsubsection{The Basic Rules}

In Germany, the Act on the Organisation of Courts determines that the court language is German and that, in cases in which a party is unable to speak and understand German, an interpreter must be engaged. ${ }^{55}$ However, since the enactment of the law in 1877 the court can, in its own discretion, ${ }^{56}$ allow the use of a foreign language in court hearings without an interpreter if all parties and the court know the foreign language ${ }^{57}$ Regarding documentary evidence in a foreign language, the situation is similar; $; 8$ the court has discretion in deciding on the necessity of a translation. ${ }^{59}$

During the last decades, courts have become more and more willing to accept English documents, and sometimes courts have indeed conducted hearings in English. ${ }^{60}$ Nevertheless, due to the discretion of the court, the parties cannot foresee with certainty whether the court will accept English documents and whether it will proceed in English language. Moreover, according to the traditional view, the relevant provisions only allow that parts of the proceedings, but not the proceedings as a whole, be conducted in a

\footnotetext{
49 Federal law on the Federal Patent Court (Bundesgesetz über das Bundespatentgericht [Patentgerichtsgesetz, PatGG]) of 20 March 2009.

50 Rhaeto-Romanic is an official language only in communications with Swiss nationals who speak Rhaeto-Romanic, $c f$. above n. 42.

${ }_{51}$ Art. 36(3) 1st sentence PatGG.

52 Art. 36(3) 2nd sentence PatGG.

53 Art. 36(4) PatGG.

54 Art. 26 PatGG.

55 Originally $\S \S 186 \mathrm{ff}$. Gerichtsverfassungsgesetz (GVG) of 27 January 1877, Official Journal of the German Empire (Reichsgesetzblatt, RGB1.) p. 41; today $\S \S 184 \mathrm{ff}$. GVG.

56 State Labour Court (Landesarbeitsgericht) Cologne, judgment of 18 February 2000, 11 Sa 1268/99, Monatsschrift für Deutsches Recht (MDR) 2000, 1337, juris-mn. 16.

$57 \S 185(2)$ and (3) GVG and Ewer, above n. 27, at 1323; for criminal matters, see $\S 187 \mathrm{GVG}$ and Federal Supreme Court (Bundesgerichtshof, BGH), judgment of 9 November 2011, 1 StR 302/11, original court document at 14ff. (mn. 29ff.), available at <http://juris.bundesgerichtshof.de/cgi-bin/rechtsprechung/ document.py?Gericht=bgh\&Art=en\&sid=d438 eadfacfc 133 b7281 da447ece67a2\&nr=58696\&pos=0\&a $\mathrm{nz}=1>$ (last visited 28 July 2012).

58 See, e.g. Supreme Court of the German Empire (Reichsgericht, RG), judgment of 20 December 1939, II 101/39, RGZ 162, 282, 287; Court of Appeals Berlin (Kammergericht, KG), judgment of 12 October 2010, 5 U 152/08, Gewerblicher Rechtsschutz und Urheberrecht - Rechtsprechungs-Report (GRUR-RR) 2011, 263, juris-mn. 37; and $c f$. also § 142(3) ZPO.

59 RG, judgment of 28 March 1883, I 195/83, RGZ 9, 430, 436f.

60 Cf. C. Armbrüster, 'Fremdsprachen in Gerichtsverfahren', 64 NJW 812, at 813-815 (2011); Huber, above n. 15, at 246; and Jauernig and Hess, above n. 10, at 32 ( $\$ 6 \mathrm{mn} .7)$.
} 
foreign language.$^{61}$ The complaint and other briefs to the court and the opposing party as well as the decisions of the court and the record must be in German; a complaint or brief in a foreign language may, however, have effects regarding the statutes of limitation. ${ }^{62}$

\subsubsection{The Project in the Circuit of the Court of Appeals of Cologne}

To remedy this situation, the Court of Appeals of Cologne and the District Courts in its circuit - the District Courts of Aachen, Bonn and Cologne - have, in January 2010, started a pilot project. ${ }^{63}$ Based on an extensive interpretation of the existing law presented above, ${ }^{64}$ the District Courts have created special chambers ${ }^{65}$ and the Court of Appeals has created a special senate ${ }^{66}$ which, on common application of the parties, promise to accept English documents without translation and to conduct hearings in English without an interpreter. According to the general rules, the chambers and the senate all consist of three professional judges. ${ }^{67}$

Applying the classification of measures presented above, the project adopts the first measure - documentary evidence in English - and the third measure - hearings in English. The other measures are not provided for. In particular, the file and the decisions are in German.

As to the implementation, we find the requirement that both parties must agree. Furthermore, we find that the project is restricted, first, to civil matters within the jurisdiction of the District Court, i.e. cases in which the value in dispute exceeds 5,000 Euro, ${ }^{68}$ and, second, to cases that present an 'international' issue. ${ }^{69}$ Despite these

Cf. L. Lässig, Deutsch als Gerichts- und Amtssprache (1980), at 19; and Huber, above n. 15, at 246.

${ }^{62} C f$. $\S$ 185(1) 2nd sentence GVG; § 4(3) Gesetz zur Ausführung zwischenstaatlicher Verträge und zur Durchführung von Verordnungen und Abkommen der Europäischen Gemeinschaft auf dem Gebiet der Anerkennung und Vollstreckung in Zivil- und Handelssachen (Anerkennungs- und Vollstreckungsausführungsgesetz - AVAG) of 19 February 2001, Official Journal of the Federal Republic of Germany (Bundesgesetzblatt, BGB1.) I, p. 288, predecessor § 3(2) Gesetz zur Ausführung des Übereinkommens vom 27. September 1968 über die gerichtliche Zuständigkeit und die Vollstreckung gerichtlicher Entscheidungen in Zivil- und Handelssachen of 29 July 1972, BGB1. I, p. 1328; see Armbrüster, above n. 60, at 813; Lässig, above n. 61, at 16-18; and C. Hoppe, 'Englisch als Verfahrenssprache Möglichkeiten de lege lata und de lege ferenda', 30 Praxis des Internationalen Privat- und Verfahrensrechts (IPRAx) 373, at 374f. (2010).

63 OLG Köln/Rechtsanwaltskammer Köln, Press Release of 15 January 2010, available at <www.rakkoeln.de/datapool/page/488/Handout_GerichtsspracheEnglisch_Vita.pdf> (last visited 28 July 2012); for a detailed presentation in English language, see S. Huber, 'The German Approach to the Globalisation and Harmonisation of Civil Procedure: Balancing National Particularities and International Open-Mindedness', in X.E. Kramer and C.H. von Rhee (eds.), Civil Litigation in a Globalising World (2012) 291, at 296, 305; and Huber, above n. 15, at 247.

${ }_{64} C f$. Armbrüster, above n. 9, at 102; S. Grillemeier, 'Englisch als Gerichtssprache: Kölner Topjuristen unterstützen OLG-Initiative', JUVE.de of 15 January 2010, available at <www.juve.de/nachrichten/ namenundnachrichten/2010/01/englisch-als-gerichtssprache-kolner-topjuristen-unterstutzen-olginitiative $>$ (last visited 28 July 2012).

${ }_{65}$ LG Aachen: 14th Chamber for Private Law Matters, cf. LG Aachen, 'Geschäftsplan 2011', at 37, available at <www.lg-aachen.nrw.de/wir_ueber_uns/geschaeftsverteilung/GVP-2011.pdf>; LG Bonn: 19th Chamber for Private Law Matters, $c f$. LG Bonn, 'Geschäftsverteilung 2012', at 27f., available at <www.lgbonn.nrw.de/10_wir_ueber_uns/120_GVP/Geschaeftsverteilungsplan_2012.pdf>; and LG Cologne: 38th Chamber for Private Law Matters, $c f$. LG Köln, 'Geschätsverteilung 2012', at 43, available at <www. lg-koeln.nrw.de/wir_ueber_uns/geschaeftsverteilung/Geschaeftsplan_2012.pdf> (all last visited 29 April 2012).

66 28th Senate for Private Law Matters, cf. OLG Köln, 'Geschäftsverteilung 2012', at 53, available at <www.olg-koeln.nrw.de/001_wir_ueber_uns/002_geschaeftsverteilung/gvp_senate_2012.pdf> (last visited 28 July 2012).

67 The law provides that in the District Court, cases are normally tried by a single judge of a chamber unless the case presents particular difficulties. It seems to be envisaged, however, that cases which are part of the project will be dealt with by three judges; $c f$. on the first such case C. Tod, 'Bonn: Premiere für Gerichtsverhandlung auf Englisch', JUVE.de of 20 May 2010, available at <www.juve.de/nachrichten/ verfahren/2010/05/nl101910> (last visited 28 July 2012).

${ }_{68} C f . \S \S 23 \mathrm{Nr} .1,71(1) \mathrm{GVG}$.

$69 C f$. the definition of cases with which the special chambers can deal in the District Courts' docket assignment plans, above n. 65 . 
limitations, it is the hope of the president of the Court of Appeals that the project may, in the long run, convince parties to international transactions to select one of these courts as forum. ${ }^{70}$ A number of well-known lawyers of the circuit have welcomed the project and announced that they will propose their clients to consider litigating in one of these courts in suitable cases. ${ }^{71}$ To date, two cases have been filed and one has been tried under the regime of the project. ${ }^{72}$

\subsubsection{The Draft Bill on 'Chambers for International Commercial Matters'}

Much more ambitious than the project of the Court of Appeals of Cologne is a draft bill on introducing 'chambers for international commercial matters'. The first draft of the bill has been prepared on the initiative of the German states of North Rhine-Westphalia and Hamburg, and found immediate support from the states of Hesse and Lower Saxony. After some deliberations, the Upper House of the German Parliament in which all 16 German states are represented (the 'Bundesrat') has, on 27 January 2010, adopted an amended draft bill. ${ }^{73}$ Accompanied by a - rather cautious - statement from the Federal Government, this bill has been sent to the Lower House, the Federal Parliament (the 'Bundestag'). ${ }^{74}$ On 9 November 2011, the Bundestag heard experts on the draft, who were mostly in favour of the proposal. ${ }^{75}$ The draft bill provides that the German states may create, on the District Court level, 'chambers for international commercial matters', consisting of one professional judge and two lay judges with professional experience in international business. These 'chambers for international commercial matters' are a special type of the 'chambers for commercial matters' - chambers consisting of one professional judge and two lay judges, introduced in 1877 and since then very highly esteemed by litigants. The jurisdiction of the 'chambers for commercial matters' is restricted to cases involving issues of commercial law. ${ }^{76}$ If, in addition, the case presents an international issue and the parties agree that it be dealt with in English language,${ }^{77}$ the complete proceeding in the District Court as well as in the Court of Appeals, including the file and the court's decisions, is to be in English. ${ }^{78}$ Only regarding the third instance level, i.e. in the Federal Supreme Court - the highest court in civil matters in Germany -, the draft bill provides that the court has discretion as to whether or not it deals with the case in English. ${ }^{79}$

In the classification of measures presented above, the project would, in the first and second instance, cover all five of them and thus exploit the possibilities to the fullest. The same holds in the third instance, if - but only if - the Federal Supreme Court so decides ${ }^{80}$ However, the draft bill reserves the possibility of the court to order the

$70 \quad C f$. Grillemeier, above n. 64.

71 Id.

$72 C f$. J. Riedel, 'Anhörung zum Entwurf eines Gesetzes zur Einführung von Kammern für internationale Handelssachen' of 31 October 2011, at 7, available at <www.bundestag.de/bundestag/ausschuesse17/ a06/anhoerungen/archiv/15_KfiHG/04_Stellungnahmen/Stellungnahme_Riedel.pdf $>$ (last visited 28 July 2012); M. Kummermehr, 'Zur englischen Sprache vor deutschen Gerichten', 65 Neue Justiz (NJ) 195, at 196 (2011); on the first case in the District Court of Bonn, see Tod, above n. 67; and Fink, above n. 23.

73 BR-Drucks. 42/10, above n. 25. For a discussion in English language, see also Huber, above n. 63, at 296f., 305-311.

74 Bundestag, 'Entwurf eines Gesetzes zur Einführung von Kammern für internationale Handelssachen (KfiHG)', BT-Drucks. 17/2163 of 16 June 2010, available at <http://dipbt.bundestag.de/dip21/ btd/17/021/1702163.pdf> (last visited 28 July 2012).

75 Bundestag, 'Ja zu englischsprachigen Gerichtsverhandlungen', report and statements of the experts available at <www.bundestag.de/dokumente/textarchiv/2011/36400205_kw45_pa_recht/> (last visited 28 July 2012)

$76 § 95 \mathrm{GVG}$

7 Cf. draft of the 1 st sentence of a new $\S 114 \mathrm{~b}$ GVG.

$C f$. draft of the 1st and 2nd sentences a new $\S 184(2)$ GVG.

$C f$. draft of the 1st sentence of a new $\S 184(3)$ GVG.

80 According to the draft bill, if the Federal Supreme Court decides to deal with the case in English, the rules which govern the proceedings in the 1st and 2nd instance apply (draft of the 2 nd sentence of a new $\S 184(3)$ GVG). This means that the Federal Supreme Court has no discretion as to which measures it takes. 
presence of an interpreter or to decide that the proceedings be dealt with in German. ${ }^{81}$ It follows from the context, though, that the drafters of the bill want this to be the exception. Therefore, we must assume that the discretion of the court to do so is limited. The court must call an interpreter or deal with the proceedings in German on motion of a third party who is drawn into the proceedings without previous consent, i.e. by way of impleader. ${ }^{82}$ Interestingly enough, this does not apply if the third party joins the proceedings on its own initiative.

The implementation would again be characterised by the necessity of party agreement, a restriction not only to cases within the jurisdiction of the District Court, but also within the jurisdiction of the 'chambers for commercial matters', and a requirement of 'internationality' of the case at issue.

It remains to be seen whether this draft bill will ever become enacted law. Although it has come relatively far in the legislative process, the legislature as a whole does not seem to be as fascinated with the idea as its proponents are. Most recently, a high official of the Federal Ministry of Justice has expressed considerable doubt, pointing to the fact that only very few proposals of the Bundesrat have ever been successful in the past and that the election period has passed its zenith. ${ }^{83}$ Moreover, the project coincides with a controversial petition to amend the constitution with an article stating expressly that German is the official language of the country ${ }^{84}$ Last but not least, the project has received considerable criticism - which leads us over to the next section.

\section{The Criticism}

It follows from the preceding presentation of the projects that the German initiative to allow for completely English proceedings in international commercial cases goes particularly far. Therefore, we should not be surprised that it is Germany where the projects have spurred the most severe criticism. For this reason, the following discussion of the criticism the projects have received will predominantly provide references to German publications. However, the arguments put forward are by no means limited to the German initiative. In an attempt to structure the discussion, we will deal with the criticism under three headings: Practical concerns, public policy concerns and legal concerns. Of course, this does not mean that there are no interdependencies among the various arguments, as will become clear through the following discussion.

\subsection{Practical Concerns}

\subsubsection{Qualification of Lawyers, Judges and Court Staff}

A first and obvious practical concern is that lawyers, judges and court staff in a country in which English is no official language lack the necessary linguistic qualification for dealing with a case in English. Such a lack of qualification may be the source of misunderstandings and conscious or unconscious restrictions of arguments, which, in the worst case, affect the final decision to the detriment of justice. ${ }^{85}$ Misunderstandings

$81 \quad C f$. draft of the 3rd sentence of a new $\S 184(2)$.

$82 C f$. draft of the 4 th sentence of a new $\S 184(2)$.

83 Report from the Federal Ministry of Justice on the conference of the association of civil procedure teachers in Halle on 30 March 2012.

${ }_{84} C f$. Bundestag, "Deutsch ins Grundgesetz" Petition stößt auf Skepsis', available at $<$ www.bundestag. de/dokumente/textarchiv/2011/36382677_kw45_pa petitionen/> (last visited 28 July 2012).

${ }_{85}$ Cf., e.g. J. Hübner, 'Sprachfehler vor Ḡericht', 48 Sprachnachrichten 9, at 9 (December 2010), available at <www.vds-ev.de/images/stories/startseite/sprachnachrichten/sn2010-04.pdf> (last visited 28 July 2012); G. Huvelin, 'Création d'une chambre internationale au tribunal de commerce de Paris', Blog entry of 13 December 2010, available at $<\mathrm{http} / /$ avocats.fr/space/gilles.huvelin/content/creation-d-39-une-chambreinternationale-au-tribunal-de-commerce-de-paris D6285E50-C9D6-436C-A5E7-F3E72AF6ECF7> (last visited 28 July 2012); v. Münch, above n. 17, at 81; U. Retzki, 'Schleichender Justizmord', 46 Sprachnachrichten 10, at 10 (June 2010), available at <www.vds-ev.de/images/stories/startseite/ sprachnachrichten/sn2010-02.pdf> (last visited 28 July 2012); Bar Association (Rechtsanwaltskammer, on 
or just an insufficient knowledge of English may cause delay and produce costs for the courts, the parties and the legal profession. Beyond that, the necessity to use a foreign language may make lawyers, judges and court staff feel uncomfortable and may even create psychological barriers. This can negatively influence their behaviour during the proceedings, e.g. their willingness to negotiate a settlement, their credibility or their ability to counter arguments of the other side. Last but not least lawyers and courts are afraid that their performance might not meet their own quality standards or that they could even ridicule themselves and thereby risk or lose their reputation. As regards courts, this fear is particularly acute if they have to render and motivate their decisions in English.

A common argument against this concern is that nowadays, many lawyers and judges have passed some time in an English-speaking country during their legal education or professional life or even hold an academic degree, like a master of laws, from a university based in such a country. Sometimes, the argument is expanded to the statement that the writing requirements of an LL.M. were not much different from what is required in English proceedings. ${ }^{86}$ Whoever earned an LL.M. degree in England or the United States knows that this argument has, of course, some merit, but is not strong enough to fully appease the concerns. Even more difficult is it to determine whether someone who had not studied or worked abroad possesses a sufficient knowledge. On the other hand, if all parties are aware of the difficulties and behave in a cooperative manner, the problems do not seem insurmountable. Were it otherwise, there would not be any arbitral proceedings with parties or arbitrators who are no native speakers. As is widely known, this is definitely not the case.

\subsubsection{Problems of Translation}

Somewhat different, but related is the argument that each law has its own terminology and that exact translations of terms and the legal concepts behind them are sometimes not possible, so that even a perfectly qualified lawyer or judge may not always be able to provide a correct translation.$^{87}$ Adding to this problem, the critics say, is the fact that only a small number of laws is available in English, and almost never is there an official translation. ${ }^{88}$

One may counter that these problems are most relevant if the applicable law is not the law of an English-speaking country. However, remembering that one of the purposes of the projects is to promote not only the selection of continental European courts, but also the choice of continental European law, this argument fades away. Nevertheless, despite all problems of translation, comparative lawyers have since long started a dialogue and over the time made impressive progress in explaining and comparing legal concepts. For those who deal with a case in English, reading foreign decisions and academic literature should present no insuperable barrier, and in our days, the necessary documents are mostly accessible in reasonable time and at a reasonable cost.

this translation, see P.L. Murray and R. Stürner, German Civil Justice [2004], at 105 fn. 84, 108) Stuttgart, Stellungnahme zum Gesetzesantrag der Länder Nordrhein-Westfalen, Hamburg - Entwurf eines Gesetzes zur Einführung für Kammern für internationale Handelssachen (KfiHG), BR Drs. 42/10 (2010), at 5, Section 6, available at $<$ www.rak-stuttgart.de/index.php?id=1165> (last visited 28 July 2012); C. Stubbe, 'Englisch als Gerichtssprache?', 43 ZRP 195, at 196 (2010); K. Tolksdorf (President of the BGH) according to ddp/dmu/sam of 5 February 2010; and see also Hoppe, above n. 62, at 376 (only for decisions in English). 86 BR-Drucks. 42/10, above n. 25, Explanatory Statement, at 8f.; Remmert, above n. 11, at 1581; F. Graf v. Westphalen, 'Englisch statt Deutsch', 8 Zeitschrift für Vertragsgestaltung, Schuld- und Haftungsrecht (ZGS) 241, at 241 (2010); cf. also the optimistic position of Dammann and Hansmann, above n. 21, at 28 (predicting that 'language barriers are unlikely to prevent a sharp increase in extraterritorial litigation').

87 For a general overview on the problems of translation, see, e.g. B. Großfeld, 'Sprache und Schrift als Grundlage unseres Rechts', 52 Juristenzeitung (JZ) 633, at 635f. (1997); and see also B. Großfeld, 'Sprache, Recht, Demokratie', NJW 1985, 1577, 1583.

${ }_{88}$ See, e.g. P. Dreesen and L. Hoffmann, 'Sprache als immanenter Teil der Rechtsordnung', 94 Kritische Vierteljahresschrift 194, at 206f. (2011). Cf., e.g. the numerous translations available at $<$ www.legifrance. $\mathrm{com} />$ with the few translations available at $<w w w . g e s e t z e-i m-i n t e r n e t . d e / T e i l l i s t e$ translations.html $>$ (both last visited 28 July 2012). 
Translations of laws would, of course, be helpful, but the parties and the judge always have to verify that the translation correctly reproduce the meaning of the original and official law. The purported problem of translation is, then, rather a problem of intellectual and professional qualification, which should not be underestimated, but does not per se exclude the use of a foreign language.

\subsection{Public Policy Concerns}

\subsubsection{Disadvantages of Non-Native Speakers}

It cannot be denied that non-native speakers have disadvantages if they must deal with a case in a foreign language. A first concern is that this could distort the competition in the sense that linguistic skills become important and may dilute the weight of, or even prevail over, professional quality, i.e. thoroughness of research and soundness of arguments ${ }^{89} \mathrm{~A}$ second concern, which builds on the first, is that the importance of linguistic skills favours lawyers who are native speakers over domestic lawyers. This could not only create an incentive for immigration of lawyers from abroad who, within the European Union, must be admitted according to the relevant EU law. ${ }^{90}$ It could also facilitate outsourcing of legal services to low-cost countries - the most recent innovation in law firm organisation. ${ }^{91}$ Both scenarios reduce the business opportunities for domestic lawyers. ${ }^{92}$

Again, these are concerns that must be taken seriously, but should not be overestimated either. First, linguistic skills are already playing a role for clients from abroad. Lawyers who are active in the field typically communicate with such clients in English, regardless of the language of the court proceedings at issue. Second, at least for the moment, it is a mere assumption that native speakers who seek admission to domestic courts are not as qualified as domestic lawyers. Third, one may wonder whether the fact that there are some very few cases that could be tried in English in continental courts is important enough to create an incentive for immigration. Fourth, only few native speakers will serve on the bench, as the law typically requires that judges have the nationality of the forum. ${ }^{93}$ It is far from clear that these judges, for whom English is not the mother tongue, would very much appreciate the pleadings of a native speaker who makes them and, possibly, the other counsel feel his or her linguistic superiority.

89 Cf. S. Fodor, 'Englisch-Fortbildung für Juristen: Notwendig oder nur "nice to have"?', 51 NJW-aktuell 32 , at 33 (2011).

90 Art. 49ff., 56ff. TFEU; Council Directive 77/249/EEC of 22 March 1977 to facilitate the effective exercise by lawyers of freedom to provide services, OJ 1977 L 78/17-18; Directive 2006/123/EC of the European Parliament and of the Council of 12 December 2006 on services in the internal market, OJ 2006 L 376/36-68; Directive 2005/36/EC of the European Parliament and of the Council of 7 September 2005 on the recognition of professional qualifications, OJ 2005 L 255/22-142; Directive 98/5/EC of the European Parliament and of the Council of 16 February 1998 to facilitate practice of the profession of lawyer on a permanent basis in a Member State other than that in which the qualification was obtained, OJ 1998 L 77/36-43. For details, see, e.g. T. Pinkel and C. U. Schmid, 'Ein Markt für transnational ausgebildete europäische Juristen?', 7 Hanse Law Review 77, at 79-116 (2011), available at <www.hanselawreview.org/ pdf11/Vol7No01Art06.pdf> (last visited 28 July 2012).

Cf. A. Geiger, 'Die Juristengeneration Y: Verlierer in der globalisierten Arbeitswelt?', 10/2012 NJWaktuell 14 (reporting that an international law firm which has already concentrated office services in Manila is planning to outsource even certain legal services).

92 Cf. Rechtsanwaltskammer Stuttgart, above n. 85, at 5, Section 6.

93 See, e.g. for Austria, Art. VII § 2(1) Nr. 1 Bundesgesetz über das Dienstverhältnis der Richterinnen und Richter, Staatsanwältinnen und Staatsanwälte und Richteramtsanwärterinnen und Richteramtsanwärter (Richter- und Staatsanwaltschaftsdienstgesetz - RStDG), BGB1. Nr. 305/1961; for France, Art. 16 n. 2 Ordonnance n. 58-1270 du 22 décembre 1958 portant loi organique relative au statut de la magistrature, J.O. of 23 December 1958, p. 11551; for Germany, § 9 Nr. 1 German Judges Law (Deutsches Richtergesetz, DRiG) of 8 September 1961, BGB1. I, p. 1665, in the version promulgated on April 19, 1972, BGB1. I, p. 713 , as amended. 


\subsubsection{Undesirable Redistribution}

The concerns about disadvantages of non-native speakers have already alluded to potentially redistributionist effects of admitting English as a court language. English as a court language may not only favour native speakers, though. It may also favour U.S.based or England-based law firms that have direct access to English-speaking lawyers, or large law firms generally because they can easily afford the costs of continuous language training for their lawyers ${ }^{94}$ and translators who are native speakers for their documents. ${ }^{95}$ More generally, admitting English as a court language could be seen as favouring 'the rich' who can afford that they or their children go to an English or U.S. high school or college or make an LL.M.

All these considerations premise that the 'size of the cake' remains the same, but that it is redistributed to the detriment of those lawyers and (potential) judges who cannot litigate in English. It is true that, to a certain degree, such redistribution may occur, if cases that would have been tried in the courts of the respective continental European country anyway, that is, in the language of the forum, will now be tried there in English. However, as explained above,${ }^{96}$ one of the primary purposes of the projects is to attract litigation, which would otherwise be dealt with in arbitral proceedings or in a court of an English-speaking country. In other words, the purpose is to make the cake larger for domestic lawyers. If this goal is achieved, the redistributionist effects do not insofar disadvantage domestic lawyers, but rather lawyers from English-speaking countries, lawyers active in representing clients in arbitral proceedings and arbitrators. This redistribution does not seem to be as objectionable; it is rather a correction of an existing distortion. Finally, the argument that only the rich could afford themselves or their children to make an LL.M. ignores that excellent students have good chances to receive fellowships from their home country or the university, and there should be nothing bad in rewarding those who are talented and invest lots of time and energy in their education. It may be true that even so, financial barriers remain. However, it would, then, probably better to seek other means to overcome these barriers than by restricting possible uses of the additional skills gathered abroad.

\subsubsection{Language Politics}

A much more general concern has its origin in language politics. In many continental European countries, a growing number of people believe that the future of their own language is threatened by languages that are, on a global scale, more common. While in other parts of the world, people are afraid of Spanish or Chinese,${ }^{97}$ in continental Europe, English is the language that is regarded to be most dangerous. From this background, the admission of English as a court language is considered another concession to the dominating language, a concession that might open the door for further intrusions. Consequently, the argument goes that admitting English in continental courts must be rejected for the sake of defending the own language. ${ }^{98}$

Of course, it is hard to predict the fate of those continental European languages that are not widely used in the rest of the world, although there is some reason to believe that they would not survive the next centuries if the international exchange of goods and services and the movement of persons and capital remain as global as they are today. Whether the admission of English in continental courts contributes to this possible

$94 \quad$ See generally Fodor, above n. 89, at 32-35.

95 Rechtsanwaltskammer Stuttgart, above n. 85, at 5, Section 6; and $c f$. also v. Münch, above n. 17, at 80f.

96 Above Section 4.

97 For a historical overview on the discussion about English as an official language in the U.S., see, e.g. D.F. Marshall, 'The Question of an Official Language: Language Rights and the English Language Amendment', 60 International Journal of the Sociology of Language 7, at 8ff. (1986). See also Coulmas, above n. 3, at 135-137.

98 T. Paulwitz, 'Einspruch im Namen des Volkes!', 11 Deutsche Sprachwelt nr. 421 (Winter 2010/11), available at <http://deutschesprachwelt.de/archiv/papier/DSW42.pdf> (last visited 28 July 2012); Retzki, above n. 85, at 10; and Hübner, above n. 85, at 9. 
development or is an inevitable consequence if European countries want to keep track is a question of faith. The direct effects of a small number of English court proceedings seem to be relatively small, the more so if, as the advocates of the projects hope, the projects recover commercial cases for continental European courts that would otherwise go to arbitration in English language or be decided in an English-speaking forum. At any rate, it appears more valuable to combat the excessive use of foreign languages in other fields, last but not least in some fields of academia. ${ }^{99}$

\subsection{Legal Concerns}

\subsubsection{Publicity of Proceedings and Democratic Control}

Courts are an arm of the State and the dispensation of justice is an act of State Authority. In a democratic system, the institutions of the State and their behaviour must be subject to control by the public. For this reason, Article 6(1) of the European Convention of Human Rights as well as national laws ${ }^{100}$ provide that court hearings must, at least as a matter of principle, be open to the public. Hearings that take place in an open courtroom but are held in a foreign language could infringe the principle of publicity of proceedings. ${ }^{101}$

Furthermore, according to a very fundamental criticism of the German draft bill on the introduction of chambers for international commercial matters, the use by the State of a language that is not the official language disregards a basic principle of democracy, the principle of democratic control of State power. This is said to be so because the State may not expect that all people are able to understand, discuss, criticise publicly and counter acts of State Authority in a foreign language. ${ }^{102}$ The infringement on the principle of democratic control is considered to be particularly severe - and not comparable to 'mere' in camera hearings, which can be allowed under certain circumstances $^{103}$ - if, as under the German draft bill, English is the language of the proceedings as a whole, including the file and the decisions. These proceedings are said to be completely withheld from the public. ${ }^{104}$

\footnotetext{
99 For other examples, see v. Münch, above n. 17, at 77.

100 See, e.g. for Switzerland Art. 45(1), (3), (4) Swiss Civil Procedure Code; for the U.S., cf., inter alia, In re Boston Herald, Inc., 321 F.3d 174, 181-82 (1st Cir. 2003); Rushford v. New Yorker Magazine, Inc., 846 F.2d 249, 253 (4th Cir. 1988); Leucadia, Inc. v. Applied Extrusion Techs., Inc., 998 F.2d 157, 161 (3d Cir. 1993); for Germany § 169 GVG; for a discussion, see U. Köbl, 'Die Öffentlichkeit des Zivilprozesses - eine unzeitgemäße Form?', in H. Hubmann and H. Hübner (eds.), Festschrift für Ludwig Schnorr von Carolsfeld (1972), at 235ff. Art. 47(2) of the Charter of Fundamental Rights of the European Union of 18 December 2000, OJ 2000 C 364/1 (now OJ 2007 C 303/1) is not directly applicable in proceedings before national courts, $c f$. T. Handschell, 'Die Vereinbarkeit von Englisch als Gerichtssprache mit dem Grundgesetz und Europäischem Recht', 88 DRiZ 395, at 399 (2010).

101 In this sense, inter alia, T. Handschell, 'Englisch als Gerichtssprache? Contra', 43 ZRP 130, at 130 (2010); Handschell, above n. 100, at 397-399; T. Hilse, Deputy's Enquiry (Kleine Anfrage) to the Senate of the City and State of Berlin of 3 May 2010, Abgeordnetenhaus Berlin, Drucks. 16/14387, at 1, Section 2., available at <www.parlament-berlin.de:8080/starweb/adis/citat/VT/16/K1Anfr/ka16-14387.pdf> (last visited 28 July 2012); Hübner, above n. 85, at 9; Lässig, above n. 61, at 19; v. Münch, above n. 17, at 81f.; A. Piekenbrock, 'Englisch als Gerichtssprache in Deutschland?', 21 Europäisches Wirtschafts- und Steuerrecht (EWS) Die erste Seite (5/2010); contra (putting emphasis on the fact that publicity is not guaranteed without any restriction, that the mere possibility of control suffices, and that it is often the media which exerts the control): BR-Drucks. 42/10, above n. 25, Explanatory Statement, at 10-12; Ewer, above n. 27, at 1324-1326; Huber, above n. 63, at 306-309; Müller-Piepenkötter, above n. 11, at 5; Prütting, above n. 23; Remmert, above n. 11, at 1582f.; and Graf v. Westphalen, above n. 86, at 241.

102 A. Flessner, 'Deutscher Zivilprozess auf Englisch. Der Gesetzentwurf des Bundesrats im Lichte von Staatsrecht, Grundrechten und Europarecht', 11 Neue Juristische Online-Zeitschrift (NJOZ) 1913, at 1914 (2011).

103 According to the German Federal Constitutional Court (Bundesverfassungsgericht, BVerfG), limitations to the principle of publicity of court sessions, like the prohibition of the direct broadcasting from hearings or the rendition of the decision, are constitutional: BVerfG, judgment of 24 January 2001, 1 BvR 2623/95, 1 BvR 622/99, BVerfGE 103, 44

104 Flessner (above n. 102, at 1914), citing a decision by which the German Federal Administrative Court, relying on the principle of democracy, decided that courts must make their decisions available for the
} 
That proceedings in a foreign language can only be directly controlled by those citizens who understand the language sufficiently well, and that even the domestic press may be reluctant to cover these proceedings, is hard to deny. However, is it really true that any such linguistic difficulty for a percentage of the population that is not absolutely insignificant violates the principles of publicity and democracy? ${ }^{105}$ In one Swiss canton, proceedings can be dealt with completely in Rhaeto-Romanic, ${ }^{106}$ a language, which was, in 2000 , only for about $0.5 \%$ of the Swiss population the language most used. ${ }^{107}$ It would be strange to conclude that, by this rule, Switzerland with its long democratic tradition grossly violated the principle of democracy. ${ }^{108}$ At any rate, as regards the contents of court decisions, the alleged problem of a lack of democratic control could be overcome or at least attenuated by providing for a mandatory translation of judgments. ${ }^{109}$ As far as democratic control of the proceedings is concerned, the fact that all legal systems know certain in camera proceedings, i.e. proceedings that are not open to the public at all, suggests that the mere use of a foreign language should be possible,${ }^{110}$ even more so if a large part of the population is quite familiar with this language. ${ }^{111}$ Taking into consideration that one purpose of the projects is to bring back cases to public courts that otherwise would have been decided in non-public arbitral proceedings, one could even argue that insofar as this goal is met, the use of English does not restrict, but promotes, publicity. ${ }^{112}$

\subsubsection{Necessity of a Constitutional Amendment}

It has also been put forward that the use of another language than the language of the constitution in any act of State Authority would presuppose an amendment of the constitution. ${ }^{113}$ Indeed, there can be no doubt that, under normal circumstances, in official communications of the state with its citizens and among different parts of the government, the official language must be used. It is far less clear, though, whether this is a constitutional principle from which one cannot deviate by regular law, but only by an amendment to the constitution, and whether this principle does not allow for an exception in cases in which all the persons that are immediately concerned agree. ${ }^{114}$ If one answers these questions in the negative, the only remaining question is whether permitting the origination of jurisprudence by domestic courts in English, which

public; see Federal Administrative Court (Bundesverwaltungsgericht, BVerwG), judgment of 22 February 1997, 6 C 3/96, BVerwGE 104, 105. See also Dreesen and Hoffmann, above n. 88, at 208f.

105 In this sense Flessner, above n. 102, at 1915; and contra Huber, above n. 15, at 250-255.

106 See, e.g. for Grisons, Art. 7f. SpG.

107 See G. Lüdi and I. Werlen, Sprachenlandschaft in der Schweiz (2005), at 7-12, available at <www.bfs. admin.ch/bfs/portal/de/index/themen/01/22/publ.Document.52216.pdf $>$ (last visited 28 July 2012). The fact that this language is, in the communication with members of this linguistic community, an official language, is only a formal matter of definition. As to the substance, this fact cannot decide on whether the proceedings in Rhaeto-Romanic violate the principle of democracy.

${ }_{108}$ The situation is somewhat similar in northern Italy where courts and public authorities must, if the parties' mother tongue is German and they so wish, use the German language; see Art. 100(1) Statuto Speciale per il Trentino-Alto Adige, Decree of the President of the Republic of 31 August 1972, nr. 670, Official Journal of the Italian Republic (Giornale Ufficiale della Repubblica Italiana, G.U.R.I.) of 20 November 1972, nr. 301, and Art. 20 Decree of the President of the Republic of 15 July 1988, nr. 574, G.U.R.I. 1989 of 8 May 1989, nr. 105, at 13.

109 Cf. also Huber, above n. 15, at 251.

110 See again Huber, above n. 15, at $253 \mathrm{f}$.

111 According to a study of the Institut für Demoskopie Allensbach, $63 \%$ of the German population believe that they speak and understand English 'passably well' ('einigermaßen gut'), see R. Schulz, Wie denken die Deutschen über ihre Muttersprache und über Fremdsprachen? (2008), at 9, available at <www.gfds. de/fileadmin/gfds_download/GfdS_Studie_Spracheinstellung.pdf $>$ (last visited 28 July 2012). Of course, there is reason to believe that many respondents were overly optimistic.

112 Hoppe, above n. 62, at 375.

113 Flessner, above n. 102, at 1916.

114 It should be mentioned that the German draft bill provides that although the decisions are taken in English, the mandate of the judgment (on this, see Murray and Stürner, above n. 85, at 334) must always be translated if it can be executed (draft of a new 4th sentence of new $\S 184(2) \mathrm{GVG}$ ), as in this case, other state authorities like a bailiff may be concerned. 
would be a source of law in the same sense as jurisprudence in the official language, is unconstitutional without a constitutional amendment. ${ }^{115}$ Even if an amendment to the constitution were necessary, this can in most countries be achieved much more easily than, e.g. in the United States.

\subsubsection{Linguistic Discrimination}

Admitting English as a court language could conflict with rules prohibiting discrimination under various aspects. First, admitting English could discriminate against those lawyers (and judges) which do not have the necessary qualifications and therefore cannot represent a client or sit on the bench in cases tried in English, to the advantage of sufficiently qualified lawyers (and judges) and, particularly, to the advantage of native speakers. ${ }^{116}$ This could conflict with the prohibition of discrimination on grounds of language ${ }^{117}$ which is a fundamental principle of European law as well as of many national legal systems. ${ }^{118}$ Although the primary focus of this prohibition is discrimination on grounds of the mother tongue, most commentators agree that these rules equally apply in cases in which only the linguistic skills are at issue. The crucial question, then, is whether this discrimination can be justified. At first sight, the idea that a new service that requires special qualifications must not be created and offered because not all potential providers have the necessary qualifications seems odd. Is this different just because the qualifications required are linguistic qualifications? Nobody would argue that a post for an English teacher or a radio spokesman for a broadcast station serving an Englishspeaking audience must be open to all teachers or radio spokesmen, regardless of whether or not they know English. Can it be different because we are not talking about a normal service, but the distribution of justice? Or because the profession of lawyer (or judge) is conceived as one single profession? Such a position is hardly defensible, as specialisation in these fields is nowadays a fact ${ }^{119}$ and has been recognized by the legislature ${ }^{120}$ as well.

Second, admitting English and English only as an additional court language in continental European courts could also infringe the general prohibition of discrimination on grounds of nationality in Article 18 TFEU or the special prohibitions in rules on the EU law's fundamental freedoms. ${ }^{121}$ Of course, the projects do not discriminate directly on grounds of nationality. However, these provisions also prohibit all forms of indirect discrimination that have similar effects. As regards the projects, their effects are indeed similar to direct discrimination in that they favour lawyers and parties from Englishspeaking member states, i.e. Great Britain, Ireland and, probably, Malta, over lawyers and parties from member states in which English is not an official or at least a common language: Lawyers and parties from the latter states do mostly not have the opportunity to litigate in their own language before the courts of other member states. ${ }^{122}$ So far, the European Court of Justice has only ruled that if another language than the official language is admitted in the courts of a member state - in the case at issue, German in the courts of northern Italy -, the use of this very language must not be restricted to cases in which the parties are nationals of the member state and belong to the part of the population for which this language is the mother tongue, but must also be open to

5 Cf. Flessner, above n. 102, at 1921f.

116 Cf. Flessner, above n. 102, at 1917-1919.

117 In this sense, inter alia, Hilse, above n. 101, at 1f., Section 5.

118 For European human rights law, see Art. 14 European Convention of Human Rights; for EU law, see Art. 21(1) Charter of Fundamental Rights, Art. 3(3)(2) TEU; for national legal systems, see, e.g. the explicit prohibition in Art. 8(2) BV Switzerland; Art. 3(3) of the German Constitution (Grundgesetz, GG) and the general prohibition in Art. 1 of the Constitution of the Netherlands (Grondwet voor het Koninkrijk der Nederlanden), Art. 10(2) of the Constitution of Belgium (De Belgische Grondwet).

119 For Germany, see Murray and Stürner, above n. 85, at 110f.

120 See, e.g. in Germany the rules on the qualification of a 'Fachanwalt' in $\S 43 \mathrm{c}$ of the Federal Attorneys Law (Bundesrechtsanwaltsordnung, BRAO).

121 In particular, Art. 45(2), 61, 65(3) TFEU. Again, Art. 21(2) of the Charter of Fundamental Rights is normally not applicable.

${ }^{122}$ Flessner, above n. 102, at 1922-1923. 
nationals of other member states who wish to use the language - in the case at issue, an Austrian and a German national indicted for traffic offences. ${ }^{123}$ The court did not have to decide on whether nationals from another member state can demand that a third language, i.e. another language than the one already admitted, be used. There should be no question that such an expansive view would go much too far. Nevertheless, it cannot be excluded that an activist court takes this position. ${ }^{124}$ The question, then, is whether this discrimination can be justified. Obviously, the idea and purposes of admitting English also provide a potential justification. First, English is, contrary to all other languages, ubiquitous in international commerce and international commercial law - and this is so despite the fact that legal English may be more difficult than general business English, as international parties nevertheless resort to English in contractual documents all the time. ${ }^{125}$ Second, the projects intend to cure or at least attenuate an already existing factual discrimination of the courts and substantive law of those countries in which it has so far not been possible to litigate in English. It is needless to say that the necessity of curing such a factual discrimination does not exist with regard to any other language. Taken together, these arguments should suffice to justify the limitation of some of the projects to English, without excluding, however, that member states offer proceedings in other languages as well if, in their specific situation, these other languages play an important role in business relationships and the admission of these languages helps to prevent or cure discrimination.

\subsubsection{Development of the Law}

A last and serious concern is that admitting English could have negative impacts on the development of the law. This concern is particularly acute where the courts also decide in English, while the applicable law is the law of their home country, which has not been formulated in English. In this case, the decision may, on the one hand, misapply domestic law; on the other hand, it may be misunderstood or simply ignored by other courts, lawyers and the academic literature for linguistic reasons only. However, even if the decisions are rendered in the official language, the fact that English was used during the proceedings by the parties' attorneys and the judge for whom this was a foreign language may have resulted in a restriction of the arguments developed and exchanged for merely linguistic reasons. It may thereby have prevented or distorted the development of the law. Furthermore, the use of English may entail an 'import' of legal principles from the common law world, which would, in part, take place unconsciously ${ }^{126}$ and, in any event, not be backed by the will of the democratically elected legislature. ${ }^{12}$

Again, this concern must be taken seriously, and it is only modestly comforting that the described impacts are not necessarily negative, but can also be beneficial. At the very least, all persons concerned should be aware of the potential problems. On the other hand, it is the purpose of the projects to bring back cases to national courts, which would otherwise be decided elsewhere. Consequently, if the projects do gain their end, there will be not only more cases but also more cases of a type that until now frequently escaped public courts, i.e. international commercial cases. There is good reason to believe that, even if the development of the law may be more cumbersome and fraught with difficulty and risks when cases are tried and decided in a foreign

ECJ, Case C-274/96, Criminal proceedings against Horst Otto Bickel and Ulrich Franz, [1998] ECR I-7637.

${ }_{124}$ Cf. also Hoppe, above n. 62, at 375 .

125 Hoppe, above n. 62, at 375. This must be emphasized against Flessner, above n. 102, at 1922-1923.

126 Cf. Maier-Reimer, above n. 1, at 2545.

127 See Hilse, above n. 101, at 1f., Section 4; and v. Münch, above n. 17, at 81. 
language, countering this flight from public civil justice ${ }^{128}$ is still extremely valuable. ${ }^{129}$ In addition, a translation of the decisions could considerably attenuate eventual negative effects. ${ }^{130}$ Finally, as regards the 'import' of foreign legal principles, it is much easier for the legislature to correct such a development if there are public court decisions than if such a development takes place in private in arbitral proceedings.

\section{The Perspectives}

The perspectives of the projects can best be evaluated if one takes into account the reactions they have provoked. On one hand, there are the projects that are limited to fewer and rather modest measures or that have been implemented for a relatively small or clearly defined area of cases only. These projects have not been accompanied by a highly publicised exposition of the motives behind them, and insofar as there has been media coverage, the emphasis was not exclusively focused on fighting the dominance of English courts and the Common Law. Apparently, these projects have not attracted much interest from academics and the general public, and have encountered no criticism at all in the respective countries.

On the other hand, there is the ambitious project of introducing 'chambers for international commercial matters' in Germany, which would realise a maximum of the possible measures and was accompanied by a very open communication of its contents and its economic goals to academics and the general public. As shown above, this project has spurred an intensive debate in the academic press and beyond, and has raised a considerable amount of fundamental and sometimes very emotional criticism that concerns the contents of the project as well as the chances of reaching the economic goals. ${ }^{131}$ Moreover, in contrast to some of the other projects, it has not yet been introduced, and its chances of realisation have definitely suffered from the acute criticism.

Should one conclude from this that ambitious projects are doomed to fail while small steps towards admitting English as a court language have a good chance, and that it is better not to speak out the economic motives behind such projects too frankly? In the short run, this may indeed be true. In the long run, though, such projects cannot be successful if introduced in secret. The concerns with proceedings in a foreign language are too important to remain hidden from academia and the public, and the risks and disadvantages can best be coped with if all parties concerned are fully aware of them. Maybe, the tempestuousness of the criticism in Germany is a consequence of an unfortunate restriction on economic arguments and the focus on the competition of legal systems. It is, of course, true that the projects could help to reinforce the position of continental law and continental courts in the competition of civil justice systems, and the author frankly admits that he would regret if this competition were lost for linguistic reasons regardless of the characteristics of procedural as well as substantive law. However, the restriction on economic arguments not only tends to make the discussion unnecessarily aggressive, but also fails to give sufficient weight to two other arguments in favour of admitting English as a court language - two arguments that have already been mentioned above but have not received the attention they deserve in the discussion in Germany: First, if we assume that admitting English as an additional court

\footnotetext{
${ }_{128}$ On this problem, see P.L. Murray, 'The Flight from Public Civil Justice', in 1 Essays in Honour of Konstantinos D. Kerameus (2009), at 847; 'Die Flucht aus der Ziviljustiz', 11 ZZPInt 295 (2006); P.L. Murray, 'The Privatization of Civil Justice', 12 ZZPInt 283, at 293-303 (2007); cf. also L.K. Doré, 'Public Courts versus Private Justice: It's Time to Let Some Sun Shine in on Alternative Dispute Resolution', 81 Chi.-Kent L. Rev. 463, at 481ff (2006).

${ }_{129} C f$. Calliess and Hoffmann, above n. 9, at 248; Hoffmann, above n. 10, at 130; and Dammann and Hansmann, above n. 21, at 18-20.

${ }_{130}$ Cf. Huber, above n. 15 , at 251 .

131 For doubts on this latter point, see, e.g. F. Niggemann, 'Englisch als Gerichtssprache in Deutschland - wirklich eine gute Idee?', 56 Recht der Internationalen Wirtschaft (RIW), Die erste Seite (10/2010); see also Illmer, above n. 7 (pointing out that the project will not meet its economic goals as long as it does not admit English as a court language in public courts' proceedings supporting arbitration); $c f$. also the lawyers quoted in H. Schwan, 'Bitte eintreten, English spoken', FAZ of 24 February 2010, at 42.
} 
language in commercial cases provides a suitable domestic forum for commercial law litigation that did not exist so far, this facilitates access to justice and thereby helps to honour the parties' legal positions in the real world. Second, if we again assume that admitting English as an additional court language brings back cases to the public court system that, to date, are decided secretly and without democratic control in arbitration, this contributes to the development of the law, its transparency and the democratic legitimacy of binding decisions. It is the author's position that these two arguments alone should suffice to allow even ambitious projects of using English in continental courts for international commercial cases, provided that there is a valid agreement of the parties to proceed in English, that judges and court staff are sufficiently qualified and that decisions are translated and thus made available to the interested public. 